\title{
PERSEPSI MASYARAKAT TERHADAP RENCANA PEMBANGUNAN EKOWISATA KARST DI DESA SAMBUEJA, KECAMATAN SIMBANG, KABUPATEN MAROS
}

\author{
Sosial Perception of Plan Development Karst Ecotourism in Sambueja, Simbang, Maros \\ Asar Said Mahbub ${ }^{1}$, Andi Wahyunira² ${ }^{2}$ Amran Achmad ${ }^{1 凶}$ \\ ${ }^{1}$ Afiliasi penulis pertamaStaf Pengajar, Fakultas Kehutanan, Universitas Hasanuddin, Makassar \\ 2Mahasiswa, Laboratorium Konservasi Sumberdaya Hutan dan Ekowisata, Universitas Hasanuddin, Makassar \\ ${ }^{\circledR}$ corresponding author: amhutan@yahoo.com
}

\begin{abstract}
Sambueja Village is one of the villages in Maros Regency which has a karst area that must be protected in total because its function as a water storage and has a variety of ecotourism potential that can be developed and can support the development of ecotourism activities. The role and participation of the community in ecotourism is an important thing that distinguishes it from other forms of tourism. Because perception is a fundamental element that needs to be known before planning activities that will involve the local community. This study aims to determine the public perception of the karst ecotourism development plan in Sambueja Village, Simbang District, Maros Regency. The results of the study can be seen that the perception of the people of Sambueja Village is a positive perception of the karst ecotourism development plan. The majority of the community stated that they did not object if the village of Sambueja was built and developed as an ecotourism village, but it requires that its development and development must refer to the concept of tourism which takes into account the preservation of environmental functions, ecological potential and maintaining cultural values in the local community.
\end{abstract}

Key words: Sosial Perception; Karst Ecotourism

\section{A. PENDAHULUAN}

Indonesia sangat dikenal sebagai salah satu negara yang memiliki keanekaragaman hayati tertinggi di dunia yang bahkan dikatakan sebagai salah satu megabiodiversity country di dunia yang merupakan aset yang sangat penting (Supriatna, 2008). Namun sejak lama, telah terjadi perusakan hutan dan penyalahgunaan lingkungan sehingga terjadi penyusutan dan kepunahan keanekaragaman hayati. Luas hutan Indonesia pada tahun 1950 mencapai 162,29 juta ha sedangkan saat ini menurut data Kementrian Lingkungan Hidup dan Kehutanan (2016), total luas hutan yang tersisa hanya 124 juta ha. Kesalahan dalam pengelolaan hutan akan mengganggu keberlangsungan makhluk hidup. Salah satu upaya untuk mencegah kesalahan dalam pengelolaan hutan adalah mempelajari dan mengerti bagaimana mengelola hutan dengan baik dan benar.

Potensi industri pariwisata saat ini banyak dikaitkan dan dipakai sebagai wahana pemecahan masalah yang saat ini dihadapi didunia, seperti kemiskinan kehilangan sumber daya alam dan isu-isu lingkungan lainnya. Hakim (2004) menyatakan bahwa industri wisata dipandang mempunyai peluang untuk aktif berperan dalam konservasi dan pembangunan berkelanjutan dengan mendesain suatu konsep wisata berbasis konservasi.

Ekowisata merupakan perjalanan wisata yang berbasis alam yang kegiatannya sangat bergantung kepada alam, sehingga lingkungan, ekosistem dan kearifan-kearifan lokal yang ada di dalamnya harus dilestarikan keberadaannya (Yoeti, 2008). Departemen Kebudayaan dan Pariwisata Indonesia (2009) menyatakan bahwa ekowisata bertujuan untuk menikmati dan mempelajari mengenai alam, sejarah dan budaya di suatu daerah yang pola wisatanya membantu ekonomi masyarakat lokal dan mendukung pelestarian alam.

Desa Sambueja merupakan salah satu desa yang ada di Kabupaten Maros yang memiliki kawasan karst yang yang harus dilindungi secara total karena fungsinya sebagai tempat penyimpanan air dan saat ini sementara diusulkan menjadi kawasan ekosistem esensial. Desa Sambueja memiliki potensi ekowisata yang cukup beragam yang dapat dikembangkan dan dapat mendukung pengembangan untuk ekowisata.

Tahun 2015, PT. Conch Maros South Sulawesi Mine yang berasal dari Cina berencana melakukan penambangan pada kawasan karst yang ada di Desa Sambueja. Namun, berdasarkan hasil Analisis Mengenai Dampak Lingkungan (AMDAL) maka usulan 
penambangan tersebut ditolak (Amran Achmad, Komunikasi Pribadi 18/04/2016). Bila kegiatan ekowisata bisa diwujudkan, maka masyarakat akan menjaga kawasan karst yang ada di sekitarnya dari kegiatan pertambangan yang mungkin terjadi sehingga fungsi lindungnya tetap berkelanjutan dan dapat memberikan kontribusi pendapatan ekonomi masyarakat di Desa tersebut.

Perencanaan pengelolaan suatu kawasan untuk tujuan ekowisata memerlukan data yang akurat dan representatif. Data-data tersebut harus didasarkan pada situasi dan kondisi terkini. Salah satu data mendasar yang perlu dikumpulkan adalah data tentang persepsi masyarakat. Persepsi masyarakat merupakan pandangan yang akan mengarahkan respek masyarakat dalam menanggapi fenomena yang ada di sekitarnya. Masyarakat harus dilibatkan dan diperhatikan presepsinya dalam pengelolaan lingkungan. Karena itulah persepsi merupakan elemen mendasar yang perlu diketahui sebelum merencanakan kegiatan yang akan melibatkan masyarakat setempat.

Penelitian ini bertujuan untuk untuk mengetahui persepsi masyarakat terhadap rencana pembangunan ekowisata karst di Desa Sambueja, Kecamatan Simbang, Kabupaten Maros. Kegunaan dari penelitian ini diharapkan dapat meningkatkan peran serta masyarakat lokal dalam mengembangkan sektor ekowisata dan mendorong pemerintah untuk lebih mendukung berkembangnya ekowisata.

\section{B. METODE PENELITIAN}

\section{Alat dan Objek Penelitian}

Alat yang digunakan dalam penelitian ini yaitu:

1. Pedoman Wawancara

2. Alat tulis menulis digunakan untuk mencatat hasil pengamatan

3. Kamera digital, digunakan untuk mengkombinasikan kegiatan penelitian

Bahan atau objek yang diamati adalah masyarakat di Desa Sambueja, Kecamatan Simbang, Kabupaten Maros, Provinsi Sulawesi Selatan.

\section{Jenis Data dan Sumber Data}

Data yang diperlukan dalam penelitian ini dibagi menjadi data primer dan data sekunder. Data primer adalah data yang diperoleh melalui wawancara dengan narasumber, yaitu melakukan penelusuran terhadap masyarakat tentang bagaimana persepsinya mengenai rencana pembangunan ekowisata di Desa Sambueja, Kecamatan Simbang, Kabupaten Maros, Provinsi Sulawesi Selatan. Data sekunder merupakan data yang menyangkut keadaan umum lokasi penelitian dan keadaan sosial ekonomi masyarakat Desa Sambueja yang diperoleh melalui studi literatur.

\section{Metode Pengumpulan Data}

Adapun teknik pengumpulan data tersebut adalah sebagai berikut:

Wawancara, yaitu pengumpulan data dengan melakukan tanya jawab langsung kepada narasumber. Wawancara tersebut digunakan untuk menemukan informasi tunggal (Moleong, 1997). Dalam penelitian ini, peneliti menggunakan wawancara secara semi terstruktur dengan pejabat perangkat desa dan masyarakat yang menjadi narasumber. Maka sebelum melakukan wawancara, peneliti telah menyiapkan pertanyaanpertanyaan yang nantinya akan diajukan kepada narasumber. Metode pengambilan sampling dilakukan dengan dua tahap. Pada tahap awal, dilakukan pengambilan sampling sebanyak $5 \%$ berdasarkan metode purposive yakni ditentukan dengan sengaja pada masyarakat Desa Sambueja yang tinggal di tiga dusun yang berdekatan dengan areal karst. Hal ini berarti bahwa telah dipilih sebanyak 60 kepala keluarga sebagai responden berdasarkan kriteria diatas. Selanjutnya, dari 60 responden tersebut dilakukan metode stratifikasi berdasarkan mata pencaharian mayarakat. Berdasarkan hal tersebut, maka jumlah responden dari petani sebanyak 31 kepala keluarga, buruh sebanyak 10 kepala keluarga, supir sebanyak 6 kepala keluarga, PNS sebanyak 7 kepala keluarga, dan pedagang sebanyak 6 kepala keluarga.

Studi literatur, yaitu pengumpulan data-data sekunder yang mendukung penelitian melalui pengutipan dan pencatatan data-data dari kantor desa, kecamatan, kabupaten, BPS, instansi yang terkait dan laporan yang ada hubungannya dengan penelitian.

\section{Metode Analisis Data}

Data hasil wawancara dari narasumber diolah ke dalam bentuk uraian-deskriptif terperinci. Dilakukan juga analisis data kualitatif. Data kualitatif akan diolah melalui tiga tahapan yaitu sebagai berikut:

a. Reduksi data yaitu merangkum, memilih hal-hal pokok, memfokuskan pada hal-hal yang penting, dan mencari tema serta pola data yang diperoleh untuk mengindentifikasi persepsi masyarakat terhadap perencanaan pengembangan ekowisata di Desa Sambueja, Kecamatan Simbang, Kabupaten Maros.

b. Penyajian data yaitu menyajikan data yang sudah diperoleh menjadi teks naratif untuk memperluas makna informasi yang diperoleh dari wawancara dalam bentuk uraian singkat, bagan, hubungan antar kategori, flowchart, dan lain-lain. Upaya ini dilakukan untuk mempermudah peneliti dalam mengorganisir data, menyusun pola dan memahami data yang diperoleh.

c. Penarikan kesimpulan yang menghasilkan temuan baru atas obyek penelitian. Penarikan kesimpulan adalah usaha guna mencari atau memahami makna, keteraturan pola-pola penjelasan, alur sebab akibat. 


\section{HASIL}

\section{Profil Responden}

\section{Luas dan Keadaan Penduduk}

Desa Sambueja merupakan salah satu desa di wilayah Kecamatan Simbang yang secara administratif terbagi atas tiga dusun yaitu Dusun Sambueja, Dusun Sambueja Tanalompoa dan Dusun Aloro dengan rata-rata jumlah penduduk per kepala keluarga sebanyak $3-4$ orang.

\section{Umur}

Umur responden berkisar 18 - 73 tahun dengan ratarata 49 tahun. Adapun sebaran frekuensi umur responden tersaji pada Tabel 1 .

Merujuk pada tabel 2, responden di Desa Sambueja memiliki potensi untuk terlibat pada berbagai aktivitas ekowisata meskipun terdapat responden yang berumur lebih dari 55 tahun atau termasuk kedalam golongan usia non produktif ada sekitar $30 \%$. Potensi sekitar $70 \%$ dari responden berumur kurang dari 55 tahun atau termasuk ke dalam golongan usia produktif nantinya dapat dimanfaatkan untuk mengelola ekowisata karst dengan berbagai upaya pemberdayaan.

Faktor umur menjadi hal penting untuk mengetahui sejauh mana tingkat keterlibatan masyarakat dalam dalam kegiatan ekowisata karst di Desa Sambueja. Hal ini selaras dengan penggarisan Nursalam dan Pariani (2001) bahwa semakin bertambah umur akan semakin berkembang pula daya tangkap dan pola pikirnya, sehingga pengetahuan yang diperolehnya semakin membaik.

\section{Tingkat Pendidikan}

Tingkat pendidikan responden yang diukur merupakan jenjang pendidikan terakhir yang telah ditamatkan. Masyarakat di Desa Sambueja sebagian besar masih berpendidikan rendah. Hal ini didukung oleh kenyataan bahwa sebagian besar dari responden mempunyai latar belakang tidak pernah bersekolah dan hanya menyelesaikan jenjang pendidikannya sampai sekolah dasar (SD) dan sekolah menengah pertama (SMP). Meskipun ada yang sudah berpendidikan perguruan tinggi tetapi jumlahnya relatif kecil, selengkapnya tersaji pada Tabel 3 .

Berdasarkan data hasil penelitian, mayoritas masyarakat Desa Sambueja berlatar belakang pendidikan yang sama sehingga dalam mengemukakan persepsinya untuk menyikapi rencana pembangunan ekowisata hampir sebagian besar mendapat respon dan jawaban yang sama. Hal ini sesuai dijelaskan oleh Arifin (2011) bahwa tingkat pendidikan akan mempengaruhi persepsi seseorang. Pendidikan mempengaruhi proses belajar, semakin tinggi pendidikan seseorang maka semakin mudah seseorang untuk menerima informasi.

Tabel 1. Sebaran Frekuensi Umur Masyarakat yang Menjadi Responden

\begin{tabular}{clcc}
\hline No. & $\begin{array}{c}\text { Umur } \\
\text { (tahun) }\end{array}$ & $\begin{array}{c}\text { Frekuensi } \\
\text { (orang) }\end{array}$ & $\begin{array}{c}\text { Persen } \\
(\%)\end{array}$ \\
\hline 1. & Kurang dari 26 & 2 & 3,3 \\
2. & $26-35$ & 12 & 20 \\
3. & $36-45$ & 7 & 11,7 \\
4. & $46-55$ & 21 & 35 \\
5. & Lebih dari 55 & 18 & 30 \\
\hline & Total & 60 & 100 \\
\hline
\end{tabular}

Tabel 2. Luas dan Keadaan Penduduk Desa Sambueja Kecamatan Simbang Kabupaten Maros

\begin{tabular}{|c|c|c|c|c|}
\hline \multirow[b]{2}{*}{ Uraian } & \multicolumn{3}{|c|}{ Dusun } & \multirow[b]{2}{*}{ Jumlah } \\
\hline & Sambueja & $\begin{array}{l}\text { Sambueja } \\
\text { Tanalompo }\end{array}$ & Alona & \\
\hline Luas $\left(\mathrm{km}^{2}\right)$ & 6,5 & 9,22 & 5,5 & 21,22 \\
\hline Jumlah KK & 786 & 172 & 91 & 1049 \\
\hline $\begin{array}{l}\text { Jumlah Penduduk } \\
\text { (jiwa) }\end{array}$ & & & & \\
\hline Laki-Laki & 1778 & 300 & 171 & 2249 \\
\hline Perempuan & 1421 & 322 & 209 & 1952 \\
\hline Jumlah & 3188 & 622 & 380 & 4190 \\
\hline Kepadatan & & & & Rata- \\
\hline $\begin{array}{l}\text { Penduduk } \\
\text { (jiwa/km²) }\end{array}$ & 490 & 68 & 69 & $\begin{array}{l}\text { rata } \\
209\end{array}$ \\
\hline
\end{tabular}

Sumber : RPJM Desa Sambueja, 2016

Tabel 3. Klasifikasi Tingkat Pendidikan Responden di Desa Sambueja

\begin{tabular}{clcc}
\hline No. & Tingkat Pendidikan & $\begin{array}{c}\text { Frekuensi } \\
\text { (orang) }\end{array}$ & $\begin{array}{c}\text { Persen } \\
(\%)\end{array}$ \\
\hline 1. & Tidak Bersekolah & 8 & 13,3 \\
2. & Sekolah Dasar (SD) & 34 & 56,7 \\
3. & $\begin{array}{l}\text { Sekolah Menengah } \\
\text { Pertama (SMP) }\end{array}$ & 9 & 15 \\
4. & $\begin{array}{l}\text { Sekolah Menengah } \\
\text { Atas (SMA) }\end{array}$ & 3 & 5 \\
5. & Perguruan Tinggi & 6 & 10 \\
\hline & Total & 60 & 100 \\
\hline
\end{tabular}

\section{Pekerjaan}

Pekerjaan responden adalah petani, buruh, supir, pedagang dan pegawai negeri sipil (PNS) dengan sebaran frekuensi dan persentase tersaji pada Tabel 4. Mayoritas masyarakat Desa Sambueja bekerja sebagai petani. Hamparan persawahan di desa ini menyebabkan kultur agraris menonjol dikalangan masyarakat. Pekerjaan sebagai buruh dan pedagang juga banyak dilakoni oleh masyarakat. Pekerjaan sebagai PNS pada umumnya berupa guru dan pegawai satuan kerja perangkat daerah. Arifin (2011) mengemukakan bahwa pekerjaan 
merupakan salah satu faktor yang mempengaruhi tingkat persepsi dan pengetahuan seseorang. Lingkungan pekerjaan dapat menjadikan seseorang memperoleh pengalaman dan pengetahuan baik secara langsung maupun tidak langsung.

Masyarakat yang berprofesi sebagai petani, pedagang dan buruh memiliki peluang untuk terlibat secara langsung pada kegiatan ekowisata karena mereka memiliki waktu yang fleksibel dan bisa menjadikannya sebagai kerjaan sampingan. Sedangkan masyarakat yang berprofesi sebagai PNS dapat menjadi promotor dalam kegiatan tersebut.

\section{Tingkat Pengetahuan Masyarakat Tentang Wisata dan Kawasan Karst serta Pemanfaatannya}

\section{Wisata}

\section{Definisi Wisata}

Seluruh reponden sudah pernah mendengar dan mengerti tentang istilah wisata. Hal ini didukung oleh kenyataan bahwa letak Desa Sambueja sangat dekat dengan beberapa lokasi wisata, salah satunya adalah Taman Nasional Bantimurung Bulusaraung. Adapaun tingkat pengetahuan masyarakat Desa Sambueja tentang wisata tersaji pada Tabel 5.

Masyarakat yang tinggal di Desa Sambueja sejak dulu juga telah terbiasa melakukan kegiatan wisata dengan mengunjungi suatu tempat wisata. Selain itu, masyarakat juga menganggap bahwa wisata bukan hanya sekedar berkunjung ke suatu tempat wisata tetapi juga menikmati pemandangan yang ada di tempat tersebut.

\section{Manfaat dan Tujuan Wisata}

Selain mengetahui istilah wisata, masyarakat juga dapat mengemukan manfaat dan tujuan wisata dari suatu kegiatan wisata. Jawaban yang diungkapkan masyarakat cukup beragam, hal ini menandakan bahwa pemahaman masyarakat tentang manfaat dan tujuan wisata sudah tinggi. Masyarakat menjelaskan bahwa yang dapat merasakan manfaat dan tujuan dari kegiatan wisata bukan hanya pengunjung saja tetapi masyarakat yang ada di sekitar lokasi wisata tersebut, dengan adanya lokasi wisata masyarakat dapat berdagang di sekitar tempat wisata tersebut untuk menambah penghasilannya.

Di sisi lain, masyarakat juga menyatakan bahwa manfaat dan tujuan dari melakukan suatu kegiatan wisata adalah untuk bersenang-senang dan menyegarkan pikiran. Hal tersebut selaras dengan Soekadijo (2000) yang menyatakan bahwa tujuan dan manfaat wisata itu adalah mengisi waktu senggang atau untuk bersenangsenang, berlibur, untuk alasan kesehatan, studi, keluarga, dan sebagainya.
Tabel 4. Sebaran Frekuensi Responden Bedasarkan Pekerjaan di Desa Sambueja

\begin{tabular}{|c|c|c|c|}
\hline No. & Pekerjaan & $\begin{array}{c}\text { Frekuensi } \\
\text { (orang) }\end{array}$ & $\begin{array}{c}\text { Persen } \\
(\%)\end{array}$ \\
\hline 1. & Petani & 32 & 53,3 \\
\hline 2. & Buruh & 8 & 13,3 \\
\hline 3. & Supir & 6 & 10 \\
\hline 4. & Pedagang & 8 & 13,3 \\
\hline 5. & $\begin{array}{l}\text { Pegawai Negeri Sipil } \\
\text { (PNS) }\end{array}$ & 6 & 10 \\
\hline & Total & 60 & 100 \\
\hline
\end{tabular}

Tabel 5. Sebaran Frekuensi Tingkat Pengetahuan Masyarakat Desa Sambueja Tentang Wisata

\begin{tabular}{clcc}
\hline No. & Pengetahuan Masyarakat & $\begin{array}{c}\text { Frekuensi } \\
\text { (orang) }\end{array}$ & $\begin{array}{c}\text { Persen } \\
(\%)\end{array}$ \\
\hline 1. & Tahu tentang wisata & 60 & 100 \\
2. & Tidak Tahu tentang wisata & 0 & 0 \\
\hline & Total & 60 & 100 \\
\hline
\end{tabular}

Tabel 6. Sebaran Frekuensi Tingkat Pengetahuan Masyarakat Tentang Istilah Kawasan Karst di Desa Sambueja

\begin{tabular}{|c|c|c|c|}
\hline No. & Pengetahuan Masyarakat & $\begin{array}{c}\text { Frekuensi } \\
\text { (orang) }\end{array}$ & $\begin{array}{c}\text { Persen } \\
(\%)\end{array}$ \\
\hline 1. & $\begin{array}{l}\text { Kawasan karst adalah } \\
\text { gunung batuan }\end{array}$ & 58 & 96,6 \\
\hline 2. & $\begin{array}{l}\text { Kawasan karst adalah } \\
\text { kawasan gunung yang } \\
\text { termasuk wilayah kehutanan }\end{array}$ & 1 & 1,7 \\
\hline 3. & Tidak tahu & 1 & 1,7 \\
\hline & Total & 60 & 100 \\
\hline
\end{tabular}

\section{Kawasan Karst dan Pemanfaatannya}

\section{Definisi Kawasan Karst}

Masyarakat yang ada di Desa Sambueja sangat menggantungkan hidupnya pada kawasan karst yang ada di Desa Sambueja. Meskipun begitu tingkat pengetahuan masyarakat tentang istilah kawasan karst di Desa Sambueja masih rendah. Kurangnya informasi yang didapatkan oleh masyarakat mengenai istilah kawasan karst, sehingga membuat masyarakat tidak mengetahui bahwa kawasan tersebut bernama kawasan karst. Hasil penelitian menunjukkan bahwa mayoritas masyarakat Desa Sambueja menyebut kawasan karst tersebut sebagai gunung batuan selengkapnya tersaji pada Tabel 6.

\section{Pemanfaatan Kawasan Karst}

Meskipun tidak mengetahui istilah kawasan karst, sebagian besar masyarakat desa sudah mengetahui manfaat dari adanya kawasan karst tersebut. Adapun sebaran tingkat pengetahuan masyarakat tentang manfaat kawasan karst dapat dilihat pada Tabel 7 . 
Tabel 7. Sebaran Frekuensi Tingkat Pengetahuan Masyarakat Tentang Manfaat Kawasan Karst di Desa Sambueja

\begin{tabular}{|c|c|c|c|}
\hline No. & $\begin{array}{c}\text { Pengetahuan } \\
\text { Masyarakat }\end{array}$ & $\begin{array}{l}\text { Frekuensi } \\
\text { (orang) }\end{array}$ & $\begin{array}{c}\text { Persen } \\
(\%)\end{array}$ \\
\hline 1. & $\begin{array}{l}\text { Sebagai tempat } \\
\text { penambangan semem, } \\
\text { batu gunung, dan } \\
\text { marmer dan sumber } \\
\text { mata air }\end{array}$ & 14 & 23,3 \\
\hline 2. & $\begin{array}{l}\text { Sebagai tempat } \\
\text { penambangan semem, } \\
\text { batu gunung, dan } \\
\text { marmer }\end{array}$ & 31 & 51,7 \\
\hline 3. & $\begin{array}{l}\text { Sebagai sumber mata } \\
\text { air }\end{array}$ & 11 & 18,3 \\
\hline 4. & $\begin{array}{l}\text { Sekitaran batuan karst } \\
\text { dapat dijadikan lahan } \\
\text { pertanian }\end{array}$ & 3 & 5,0 \\
\hline \multirow[t]{2}{*}{5.} & Tidak tahu & 1 & 1,7 \\
\hline & Total & 60 & 100 \\
\hline
\end{tabular}

Tabel 8. Sebaran Frekuensi Persepsi Masyarakat Terhadap Usulan Penambangan Karst di Desa Sambueja

\begin{tabular}{clcc}
\hline No. & Persepsi Masyarakat & $\begin{array}{c}\text { Frekuensi } \\
\text { (orang) }\end{array}$ & $\begin{array}{c}\text { Persen } \\
(\%)\end{array}$ \\
\hline 1. & Setuju & 17 & 28,3 \\
2. & $\begin{array}{l}\text { Tidak setuju } \\
\text { Mengikuti bagaimana }\end{array}$ & 41 & 68,4 \\
3. & $\begin{array}{l}\text { keputusan masyarakat } \\
\text { yang lainnnya }\end{array}$ & 2 & 3,3 \\
\hline & Total & 60 & 100 \\
\hline
\end{tabular}

Mayoritas masyarakat di Desa Sambueja telah menyadari bahwa kawasan karst tidak hanya dapat dimanfaatkan untuk penambang saja tetapi dapat dimanfaatkan melalui alternatif lain yang tidak akan merusak sumberdaya alam yang ada di sekitar desa. Hal ini dikarenakan masyarakat desa sangat menggantungkan hidupnya pada kawasan karst terutama sebagai sumber mata air untuk kegiatan pertanian dan keperluan rumah tangga sehari-hari.

Namun disisi lain, hasil penelitian juga menunjukkan adanya sebagian masyarakat tidak mengetahui manfaat karst selain tambang karena tidak dekatnya kawasan tersebut dari lokasi tempat tinggal mereka. Sehingga mereka jarang melakukan kegiatan yang berkaitan dengan kawasan karst tersebut.

\section{Usulan Penambangan Kawasan Karst}

Pada tahun 2015, kawasan karst di Desa Sambueja pernah akan di tambang. Namun, berdasarkan hasil Analisis Mengenai Dampak Lingkungan (AMDAL) maka usulan penambangan tersebut ditolak. Sebaran frekuensi persepsi masyarakat terhadap usulan penambangan karst di Desa Sambueja dapat dilihat pada Tabel 8.

Saat ini pilihan pemanfaatan dengan cara menambang bukan menjadi pilihan utama lagi, terbukti dari mayoritas masyarakat memilih sikap untuk tidak setuju dan masih kuatnya perlawanan masyarakat di kawasan Desa Sambueja untuk menolak pembangunan pabrik semen.

Masyarakat beranggapan bahwa adanya pertambangan tersebut akan membuat masyarakat akan kekurangan air untuk kegiatan sehari-hari dan mengairi lahan persawahannya terutama jika musim kemarau. Kawasan karst tersebut merupakan satu-satunya sumber air yang bisa digunakan oleh masyarakat Desa Sambueja.Sementara itu, kegiatan pertambangan juga dianggap akan mengambil banyak lahan baik lahan pertanian maupun lahan pemukiman masyarakat, sehingga masyarakat akan kesulitan untuk menemukan lokasi yang baru untuk pindah. Selain itu, masyarakat juga merasa akan sangat terganggu dengan polusi udara yang dapat ditimbulkan oleh kegiatan pertambangan tersebut, karena dapat mengganggu kesehatan masyarakat yang menyebabkan mata perih dan gangguan saluran pernafasan.

Meskipun begitu, ada beberapa masyarakat setuju dengan usulan pertambangan tersebut dengan alasan bahwa jika kegiatan tersebut dilakukan maka akan membantu masyarakat untuk meningkatkan perekonomiannya karena bisa mendapatkan pekerjaan di perusahaan tersebut dan ganti rugi yang lebih besar.

\section{Persepsi Masyarakat Terhadap Potensi Objek Wisata di Desa Sambueja}

Desa Sambueja merupakan salah satu desa yang memiliki potensi objek wisata karst yang cukup beragam namun yang berpotensi untuk dijadikan kegiatan ekowisata di kawasan tersebut belum dieksplorasi. Potensi fisik dan non fisik serta sosial budaya yang berkaitan erat dengan kawasan karst Desa Sambueja, merupakan potensi yang dapat dikembangkan dan dapat mendukung pengembangan untuk ekowisata. Berbagai potensi ekowisata yang ada menggambarkan kekayaan budaya, kearifan sosial dan kearifan lingkungan Desa Sambueja.

Adanya aliran sungai yang membentang di Desa Sambueja merupakan salah satu potensi yang dapat di manfaatkan untuk mencari ikan oleh masyarakat Desa Sambueja. Tempat tersebut dikenal dengan nama Bangkala Polloa.

Tidak hanya itu, Desa sambueja juga memiliki sumber mata air yang sangat jernih dan letaknya di dalam gua yang biasanya masyarakat menggunakan sumber mata air itu untuk memenuhi kebutuhan sehari-hari dan kegiatan pertanian mereka. Selain itu, masyarakat juga memiliki kepercayaan menjadikan sumber mata air tersebut sebagai tempat suci dan keramat. Masyarakat di sekitar Desa Sambueja menyebut tempat tersebut dengan nama Tampala. Biasanya masyarakat akan berkunjung dan berkumpul di sana pada saat-saat tertentu seperti sebelum atau setelah mengadakan hajatan/nikahan atau sebelum atau sesudah bulan Ramadhan, bulan Safar 
digunakan sebagai tempat permandian. Hal tersebut merupakan suatu adat istiadat yang dimiliki oleh Desa Sambueja.

Tabel 9. Sebaran Frekuensi Persepsi Masyarakat Terhadap Desa Sambueja yang Akan Dijadikan Kawasan Ekowisata Karst

\begin{tabular}{clcc}
\hline No. & Persepsi Masyarakat & $\begin{array}{c}\text { Frekuensi } \\
\text { (orang) }\end{array}$ & $\begin{array}{c}\text { Persen } \\
(\%)\end{array}$ \\
\hline 1. & Setuju & 44 & 73,3 \\
2. & $\begin{array}{l}\text { Tidak setuju } \\
\text { Mengikuti bagaimana } \\
\text { keputusan masyarakat yang } \\
\text { lainnnya }\end{array}$ & 4 & 6,7 \\
\hline & 12 & 20 \\
\hline & Total & 60 & 100 \\
\hline
\end{tabular}

Tabel 10. Sebaran Frekuensi Persepsi Masyarakat Terhadap Diadakannya Pendidikan dan Pelatihan Bagi Masyarakat Tentang Pengelolaan Ekowisata Karst

\begin{tabular}{llcc}
\hline No. & Persepsi Masyarakat & $\begin{array}{c}\text { Frekuensi } \\
\text { (orang) }\end{array}$ & $\begin{array}{c}\text { Persen } \\
(\%)\end{array}$ \\
\hline 1. & $\begin{array}{l}\text { Diadakannya pendidikan } \\
\text { dan pelatihan ekowisata }\end{array}$ & 60 & 100 \\
$\begin{array}{l}\text { Tidak diakannya } \\
\text { pendidikan dan pelatihan } \\
\text { ekowisata }\end{array}$ & 0 & 0 \\
\hline & Total & 60 & 100 \\
\hline
\end{tabular}

Desa Sambueja juga memiliki tradisi budaya yang memiliki nilai dan karakter tersendiri, seperti tradisi addengka ase lolo, anngaru, appalili, abbaja, dan appanaung. Semua ini merupakan tradisi yang sering dilaksanakan masyarakat.

Potensi yang dimiliki Desa Sambueja masih sangat alami dan unik. Oleh karena itu, pentingnya menjaga potensi tersebut agar tidak mengalami kerusakan dan tetap terjaga kelestariannya. Jika potensi tersebut tidak dilestarikan maka secara otomatis daya tarik pendukung ekowisata akan berkurang sehingga pada akhirnya rencana pembangunan ekowisata akan gagal. Hal ini sesuai dengan yang diungkapkan oleh Hakim (2004) menyatakan bahwa potensi industri pariwisata banyak dikaitk an dan dipakai sebagai wahana pemecahan masalah yang saat ini dihadapi didunia, seperti kemiskinan kehilangan sumber daya alam dan isu-isu lingkungan lainnya.

\section{Persepsi Masyarakat Terhadap Rencana Pembangunan Ekowisata Karst di Desa Sambueja}

\section{Persepsi Masyarakat Terhadap Dijadikannya Desa Sambueja Sebagai Kawasan Ekowisata}

Kawasan karst di Desa Sambueja sudah pernah direncanakan untuk dijadikan lokasi penambangan, untuk melindungi kawasan karst tersebut harus ada usaha peningkatan pendapatan masyarakat dalam bentuk pemanfaatan yang non destruktif, seperti kegiatan ekowisata.
Mayoritas masyarakat Desa Sambueja memilih sikap setuju dengan rencana pembangunan ekowisata karst dengan mengambil bentuk pariwisata yang bersahabat dengan alam dan lingkungan. Hal ini disebabkan masyarakat sadar akan keberadaan potensi ekologis yang dimiliki daerah mereka, seperti yang dapat dilihat pada Tabel 9 .

Terdapat beberapa masyarakat tidak setuju jika di Desa Sambueja akan dibangun sebuah tempat ekowisata. Menurut masyarakat jika kegiatan ini dilaksanakan maka akan berpotensi merusak satu-satunya sumber mata air dan letak lahan pertanian yang dekat dari kawasan karst sehingga akan memberi dampak yang merugikan untuk masyarakat di Desa Sambueja.

\section{Persepsi Masyarakat Terhadap Diadakannya Pendidikan dan Pelatihan Bagi Masyarakat Tentang Pengelolaan Ekowisata Karst}

Menyikapi penyataan diadakannya pendidikan dan pelatihan bagi masyarakat sebagai persiapan tenaga kerja di bidang ekowisata, disambut baik oleh masyarakat seperti yang dapat dilihat pada Tabel 10 berikut ini.

Seluruh responden yang ada di Desa Sambueja setuju dengan diadakannya pelatihan dan pendidikan tersebut. Alasan dari masyarakat, dengan dibekali pengetahuan dan keterampilan di bidang ekowisata maka mereka akan lebih percaya diri dalam pengelolaan kegiatan ekowisata karst di Desa Sambueja.

Masyarakat juga berpendapat jika masyarakat hanya disodori buku-buku panduan tentang ekowisata saja masyarakat merasa itu sangat kurang efektif, karena jika ada yang yang tidak dimengerti maka masyarakat akan kebingungan akan bertanya kepada siapa sehingga akan kesulitan untuk memahami materi mengenai ekowisata. Hal tersebut sesuai dengan pendapat Josephine (2010) yang mengatakan diperlukan upaya pendekatan kepada masyarakat melalui penyuluhan dan pelatihan yang bersifat meningkatkan keterampilan dan juga meningkatkan pengetahuan arti pentingnya sumber daya alam bagi keberlanjutan ekowisata.

\section{Persepsi Masyarakat Terhadap Pelibatan Masyarakat Desa Sambueja Dalam Ekowisata Karst}

Besarnya keinginan masyarakat untuk terlibat dalam rangka rencana pembangunan ekowisata karst. Hal ini dapat dilihat pada Tabel 11, dimana mayoritas responden menyatakan setuju untuk dilibatkan dalam kegiatan tersebut.

Masyarakat Desa Sambueja menyambut baik jika memang masyarakatlah yang berperan aktif dalam pengelolaannya. Jika masyarakat dilibatkan mulai sejak awal juga maka mereka akan bisa mempertanggungjawabkan apa yang mereka kerjakan. Meskipun begitu, ada beberapa dari masyarakat yang tidak bisa ikut terlibat 
karena pekerjaan tetap yang mereka miliki dan usia tua yang dimilikinya.

Tabel 11. Sebaran Frekuensi Persepsi Masyarakat Terhadap Pelibatan Masyarakat Desa Sambueja Dalam Kegiatan Ekowisata Karst

\begin{tabular}{|c|c|c|c|}
\hline No. & Persepsi Masyarakat & $\begin{array}{c}\text { Frekuensi } \\
\text { (orang) }\end{array}$ & $\begin{array}{c}\text { Persen } \\
(\%)\end{array}$ \\
\hline 1. & $\begin{array}{l}\text { Setuju untuk dilibatkan } \\
\text { dalam kegiatan ekowisata }\end{array}$ & 51 & 85 \\
\hline 2. & $\begin{array}{l}\text { Tidak setuju untuk } \\
\text { dilibatkan dalam } \\
\text { ekowisata }\end{array}$ & 4 & 6,7 \\
\hline 3. & $\begin{array}{ll}\text { Mengikuti } & \text { bagaimana } \\
\text { keputusan } & \text { masyarakat } \\
\text { yang lainnnya } & \end{array}$ & 5 & 8,3 \\
\hline & Total & 60 & 100 \\
\hline
\end{tabular}

Tabel 12. Sebaran Frekuensi Persepsi Masyarakat Terhadap Bentuk Kerlibatan Masyarakat di Desa Sambueja

\begin{tabular}{clcc}
\hline No. & \multicolumn{1}{c}{ Persepsi Masyarakat } & $\begin{array}{c}\text { Frekuensi } \\
\text { (orang) }\end{array}$ & $\begin{array}{c}\text { Persen } \\
(\%)\end{array}$ \\
\hline 1. & Tenaga pemasaraan & 1 & 1,7 \\
2. & $\begin{array}{l}\text { Tenaga pemungutan } \\
\text { retribusi }\end{array}$ & 11 & 18,3 \\
3. & $\begin{array}{l}\text { Pengelola jasa } \\
\text { akomodasilhomestay }\end{array}$ & 29 & 48,3 \\
4. & $\begin{array}{l}\text { Pengelola warung makan } \\
\text { dan ole-ole khas }\end{array}$ & 10 & 16,7 \\
5. & Tour guide & 5 & 8,3 \\
6. & Tidak terlibat & 4 & 6,7 \\
\hline & Total & 60 & 100 \\
\hline
\end{tabular}

Tabel 13. Sebaran Frekuensi Persepsi Masyarakat Tentang Pelibatan Pemerintah dan Swasta Dalam Kegiatan Ekowisata Karst di Desa Sambueja

\begin{tabular}{clcc}
\hline No. & \multicolumn{1}{c}{ Persepsi Masyarakat } & $\begin{array}{c}\text { Frekuensi } \\
\text { (orang) }\end{array}$ & $\begin{array}{c}\text { Persen } \\
(\%)\end{array}$ \\
\hline 1. & Pemerintah & 33 & 55 \\
2. & $\begin{array}{l}\text { Pihak swasta } \\
\text { Kerjasama antara } \\
\text { pemerintah dan pihak }\end{array}$ & 4 & 6,7 \\
swasta & 6 & 10 \\
$\begin{array}{l}\text { Pihak yang akan memberi } \\
\text { keuntungan pada } \\
\text { masyarakat }\end{array}$ & 17 & 28,3 \\
\hline & & \\
\hline
\end{tabular}

\section{Persepsi Masyarakat Terhadap Bentuk Keterlibatan Masyarakat Desa Sambueja Dalam Ekowisata Karst}

Ekowisata dapat memberikan manfaat sebagai lapangan kerja baru yang sangat berguna bagi kehidupan masyarakat sekitar. Salah satu bentuk keterlibatan yang diinginkan oleh kebanyakan masyarakat adalah menyediakan jasa penginapan/homestay. Menurut mereka jasa ini tidak banyak membutuhkan modal, cukup dengan mentata rumah-rumah (kebanyakan rumah panggung) mereka untuk dijadikan penginapan.

Wisatawan juga cenderung menjadikan rumahrumah tradisional sebagai tempat menginap untuk merasakan sensasi menginap di pedalaman dan perkampungan penduduk. Sebagai unsur penunjang masyarakat banyak memilih usaha warung makan ataupun oleh-oleh khas. Sedangkan yang memahami dengan baik situasi dan kondisi lingkungan sekitar memilih bekerja sebagai pemandu wisata. Adapun sebaran sebaran frekuensi persepsi masyarakat terhadap berbagai bentuk keterlibatan masyarakat dalam kegiatan ekowisata di Desa Sambueja dapat dilihat pada Tabel 12.

\section{Persepsi Masyarakat Terhadap Keterlibatan Pemerintah dan Pihak Swasta Dalam Ekowisata Karst di Desa Sambueja}

Gunawan (2008) menjelaskan bahwa kegiatan ekowisata hendaknya menjamin keikutsertaan masyarakat setempat dan perlunya interaksi ketiga pihak terlibat, yaitu sektor pemerintah, swasta dan masyarakat untuk mendukung jalannya kegiatan tersebut. Pada Tabel 13 dapat dilihat persepsi masyarakat terhadap keterlibatan pemerintah dan pihak swasta dalam ekowisata karst di Desa Sambueja.

Mayoritas masyarakat percaya bahwa jika pemerintah yang terlibat dalam membantu kegiatan ekowisata karst, masyarakat merasa akan lebih diperhatikan dan tidak akan dibodoh-bodohi sehingga akan memberi untung. Adanya kekhawatiran masyarakat jika melibatkan pihak swasta maka keuntungan yang didapat lebih banyak akan berpihak pada swasta. Namun, beberapa masyarakat juga menyatakan lebih setuju akan keterlibatan pihak swasta. Peran dari pihak luar menurut masyarakat sangat berpengaruh terhadap pengelolaan ekowisata karena alasannya masyarakat belum cukup modal dalam pengembangan ekowisata, sehingga memerlukan bantuan dari pihak swasta. Disisi lain, masyarakat juga menyarakan bahwa akan lebih baik jika pemerintah dan pihak swasta bisa bekerja sama untuk menjalankan kegiatan ini.

\section{Persepsi Masyarakat Terhadap Sarana dan Prasarana Dalam Ekowisata Karst Desa Sambueja}

Rencana pembangunan ekowisata karst ini mendapatkan tanggapan yang baik dari masyarakat terutama mengenai sarana dan prasarana yang akan digunakan pada kegiatan ini. Adapun sebaran frekuensi persepsi masyarakat terhadap bentuk keterlibatan masyarakat di Desa Sambueja dapat dilihat pada Tabel 14 di bawah ini. 
Tabel 14. Sebaran Frekuensi Persepsi Masyarakat Terhadap Sarana dan Prasarana di Desa Sambueja

\begin{tabular}{clcc}
\hline No. & \multicolumn{1}{c}{ Persepsi Masyarakat } & $\begin{array}{c}\text { Frekuensi } \\
\text { (orang) }\end{array}$ & $\begin{array}{c}\text { Persen } \\
(\%)\end{array}$ \\
\hline 1. & $\begin{array}{l}\text { Sarana dan prasarana } \\
\text { tradisional }\end{array}$ & 38 & 63,3 \\
2. & $\begin{array}{l}\text { Sarana dan prasarana } \\
\text { modern }\end{array}$ & 8 & 13,3 \\
3. $\quad \begin{array}{l}\text { Perpaduan sarana dan } \\
\text { prasarana tradisional dan } \\
\text { modern }\end{array}$ & 7 & 11,7 \\
4. $\begin{array}{l}\text { Mengikuti bagaimana } \\
\text { keputusan masyarakat yang } \\
\text { lainnnya }\end{array}$ & 7 & 11,7 \\
\hline & Total & 60 & 100 \\
\hline
\end{tabular}

Tabel 15. Sebaran Frekuensi Persepsi Masyarakat Terhadap Aksebilitas Menuju Kawasan Karst di Desa Sambueja

\begin{tabular}{clcc}
\hline No. & \multicolumn{1}{c}{ Persepsi Masyarakat } & $\begin{array}{c}\text { Frekuensi } \\
\text { (orang) }\end{array}$ & $\begin{array}{c}\text { Persen } \\
(\%)\end{array}$ \\
\hline 1. & Aksesbilitas sudah baik & 1 & 1,7 \\
2. & $\begin{array}{l}\text { Aksesbilitas masih perlu } \\
\text { diperbaiki }\end{array}$ & 59 & 98,3 \\
\hline & Total & 60 & 100 \\
\hline
\end{tabular}

Tabel 16. Sebaran Frekuensi Persepsi Masyarakat Terhadap Pemungutan Retribusi Dalam Kegiatan Ekowisata Karst di Desa Sambueja

\begin{tabular}{clcc}
\hline No. & \multicolumn{1}{c}{ Persepsi Masyarakat } & $\begin{array}{c}\text { Frekuensi } \\
\text { (orang) }\end{array}$ & $\begin{array}{c}\text { Persen } \\
(\%)\end{array}$ \\
\hline 1. & Perlu diberlakukan & 53 & 88,3 \\
2. & Tidak perlu diberlakukan & 0 & 0 \\
3. & $\begin{array}{l}\text { Mengikuti bagaimana aturan } \\
\text { dan keputusan pengelola }\end{array}$ & 7 & 11,7 \\
& & \\
kegiatan ekowisata & & \\
\hline & Total & 60 & 100 \\
\hline
\end{tabular}

Tabel 17. Sebaran Frekuensi Persepsi Masyarakat Terhadap Dampak RencanaPembangunan Kegiatan Ekowisata Karst di Desa Sambueja

\begin{tabular}{clcc}
\hline No. & Persepsi Masyarakat & $\begin{array}{c}\text { Frekuensi } \\
\text { (orang) }\end{array}$ & $\begin{array}{c}\text { Persen } \\
(\%)\end{array}$ \\
\hline 1. & Berdampak positif & 58 & 96,7 \\
2. & Berdampak negatif & 0 & 0 \\
3. & Tidak Tahu & 2 & 3,3 \\
\hline & Total & 60 & 100 \\
\hline
\end{tabular}

Rencana pembangunan ekowisata karst ini mendapatkan tanggapan yang baik dari masyarakat karena masyarakat dapat terlibat dengan memanfaatkan sarana dan prasarana yang telah miliki oleh masyarakat. Hal tersebut ini dirasa masyarakat sangat ekonomis karena masyarakat tak perlu mengeluarkan modal dan akan menjadi daya tarik tarik untuk pengunjung yang sudah bosan dengan kehidupan perkotaan. Honey (1999) juga menjelaskan bahwa Alam dan budaya adalah aset mutlak ekowisata. Keuntungan ekonomi yang diperoleh dari ekowisata harus dimanfaatkan untuk melestarikan lingkungan dan tidak mengadakan sarana yang dapat mengurangi kerusakan lingkungan. Dampak yang ditimbulkan harus ditekan sekecil mungkin.

Lain halnya, sebagian masyarakat juga menyarankan jika lebih baik membangun sarana dan prasarana yang modern karena itu akan membuat pengunjung merasa nyaman dan akan dapat memajukan desa dan tidak ketinggalan dalam pembangunan. Sedangkan ada juga masyarakat yang menyarankan untuk memperpadukan sarana dan prasarana tradisional dan modern sehingga pengunjung akan bebas menentukan pilihan.

\section{Persepsi Masyarakat Terhadap Aksesbilitas Menuju Kawasan Ekowisata Karst di Desa Sambueja}

Selain sarana dan prasarana, aksesbilitas menuju lokasi ekowisata merupakan faktor pendukung berkembangnya ekowisata. Beberapa ruas jalan di Desa Sambueja membutuhkan perbaikan dan pelebaran karena sebagian jalan ada yang rusak, belum dibeton dan sempit, karena itu responden menyatakan perlu dilakukan perbaikan agar akses menuju lokasi ekowisata dapat lebih mudah dan lancar. Sebaran Frekuensi, persepsi masyarakat terhadap aksebilitas menuju kawasan karst di Desa Sambueja selengkapnya tersaji pada Tabel 15.

\section{Persepsi Masyarakat Terhadap Pemungutan Retribusi Dalam Ekowisata Karst di Desa Sambueja}

Mayoritas masyarakat mengungkapkan pemungutan retribusi diperlukan agar dapat menambah pemasukan dalam kegiatan ekowisata untuk kepentingan pengembangan. Pemungutan restribusi juga dianggap bisa membuat kawasan ekowisata menjadi lebih aman dan tertib, selengkapnya tersaji pada Tabel 16 .

Masyarakat yang lainnya juga berpendapat bahwa akan mengikuti aturan yang diberlakukan oleh pengelola kegiatan ekowisata , selama itu menguntungkan masyarakat desa. Dinas Pariwisata Provinsi Jawa Tengah (2002) menjelaskan bahwa pemungutan retribusi diakui secara sah oleh negara, selama semua proses pembangunan objek/ daya tarik wisata di desa tersebut ada campur tangan pemerintah daerah secara khusus maka pemungutan retribusi terhadap kunjungan wisata dilakukan oleh pemerintah setempat melalui sistem target tahunan.

\section{Persepsi Masyarakat Terhadap Dampak Rencana Pembangunan Ekowisata Karst di Desa Sambueja}

Masyarakat Desa Sambueja antusias kepada rencana pembangunan ekowisata karst ini. Dari hasil data wawancara yang dapat dlihat Tabel 17 di bawah ini, menunjukkan hampir seluruh responden menyatakan rencana pembangunan kegiatan ekowisata karst di Desa Sambueja akan berdampak positif. 
Dampak-dampak yang akan timbul sehubungan dengan rencana pembangunan kegiatan ekowisata karst di Desa Sambueja pada umumnya mengarah pada dua hal yakni meningkatkan perekonomian dan sumber mata air yang ada di kawasan karst akan terjaga. Selain itu, ada juga masyarakat yang belum bisa menyimpulkan apakah berdampak baik atau buruk. Masyarakat Desa Sambueja akan merasa terganggu jika itu sudah menyangkut soal sumber mata airnya karena dari situlah kegiatan seharihari mereka bergantung, jadi sangat berhati-hati dalam melihat kegiatan apa saja yang bisa berpeluang merusak. Meskipun begitu, tidak ada masyarakat yang menyatakan bahwa kegiatan ekowisata karst ini nantinya akan berdampak negatif. Sedangkan disisi lain hanya ada dua orang responden yang menyatakan tidak mengetahui akan berdampak bagaimana kegiatan ini.

\section{PEMBAHASAN}

Tingkat pegetahuan masyarakat Desa Sambueja tentang wisata sudah tinggi. Disamping itu, masyarakat juga telah memahami manfaat dan tujuan dari suatu kegiatan wisata. Hal tersebut didukung oleh kenyataan bahwa masyarakat yang tinggal di Desa Sambueja sejak dulu juga telah terbiasa melakukan kegiatan wisata dan dekatnya lokasi Desa Sambueja dengan beberapa lokasi wisata. Pemahaman seperti ini tentu menjadi modal dasar dalam pengembangan wisata, karena setidaknya mereka sudah paham bahwa modal pariwisata apalagi wisata alam sangat mengandalkan situasi dan kondisi lingkungan yang berada di sekitar objek tersebut, serta masyarakat akan menyadari bahwa dengan pengelolaan yang baik tentu akan meningkatkan perekonomian mereka.

Fenomena lain menunjukkan bahwa tingkat pengetahuan masyarakat Desa Sambueja tentang istilah kawasan karst masih rendah. Kurangnya informasi yang didapatkan oleh masyarakat mengenai istilah kawasan karst, merupakan sebab masyarakat tidak mengetahui bahwa kawasan tersebut bernama kawasan karst. Akan tetapi, pengetahuan masyarakat tentang pemanfaatan kawasan karst sudah tinggi. Hal ini dikarenakan sangat bergantungnya kehidupan masyarakat Desa Sambueja pada kawasan karst tersebut.

Kawasan karst di Desa Sambueja dipandang sebagai suatu ekosistem yang berperan penting dalam kehidupan sehari-hari masyarakat. Terbukti dari hasil penelitian menunjukkan bahwa mayoritas masyarakat memilih sikap tidak setuju terhadap usulan kegiatan pertambangan pada kawasan karst tersebut. Pemahaman dan pandangan masyarakat terhadap usulan kegiatan pertambangan tersebut tidak terlepas dari pengetahuan masyarakat tentang bermanfaat atau tidaknya kegiatan pertambangan bagi mereka, seperti yang diperlihatkan pada Tabel 7.

Peran serta masyarakat di sekitar desa tidak bisa diabaikan karena mereka lebih tahu daerah mereka dibanding orang luar, karena itu keterlibatan masyarakat dalam berbagai kegiatan sangat diperlukan. Masyarakat telah sadar akan keberadaan potensi ekologis yang dimiliki daerah mereka dan mayoritas dari masyarakat telah setuju agar ekowisata dibangun di Desa Sambueja apalagi jika pengelolaannya banyak melibatkan masyarakat setempat. Mayoritas masyarakat Desa Sambueja telah mengerti, memahami dan berpersepsi positif terhadap manfaat pembangunan ekowisata.

Persepsi positif tentang rencana pembangunan ekowisata karst menjadi peluang bagi masyarakat berperan aktif dalam konservasi dan pembangunan berkelanjutan. Hal ini seperti yang di jelaskan oleh Departemen Kebudayaan dan Pariwisata Indonesia (2009) bahwa pola ekowisata berbasis masyarakat adalah pola pengembangan ekowisata yang mendukung dan memungkinkan keterlibatan penuh oleh masyarakat setempat dalam perencanaan, pelaksanaan, dan pengelolaan usaha ekowisata dan segala keuntungan yang diperoleh. Hal tersebut didasarkan kepada kenyataan bahwa masyarakat memiliki pengetahuan tentang alam serta budaya yang menjadi potensi dan nilai jual sebagai daya tarik wisata, sehingga pelibatan masyarakat menjadi mutlak.

Dengan adanya peran serta dari masyarakat desa dalam mengelola usaha ekowisata maka masyarakat akan bisa menikmati secara langsung pendapatan dari sumbersumber alam mereka sendiri, akhirnya secara perlahanlahan akan timbul perasaan untuk tetap menjaga dan melestarikan sumber daya alam. Menurut Yoeti (2000) dan Achmad (2017) bahwa ekowisata akan memberikan dampak langsung terhadap konservasi kawasan, berperan dalam usaha-usaha pemberdayaan ekonomi masyarakat lokal sehingga terbangun rasa memliki mereka akan sumberdaya alam di sekitarnya, sehingga masyarakat terdorong untuk melakukan konservasi untuk pembangunan berkelanjutan, dan bahkan menjadi alat perekonomian di negara-negara berkembang.

\section{E. KESIMPULAN}

Persepsi dari masyarakat Desa Sambueja adalah persepsi yang positif terhadap rencana pembangunan ekowisata karst. Mayoritas masyarakat menyatakan tidak keberatan apabila di Desa Sambueja dibangun dan dikembangkan sebagai desa ekowisata, namun mensyaratkan bahwa pembangunan dan pengembangannya harus mengacu pada konsep pariwisata yang memperhatikan pelestarian fungsi lingkungan, potensi ekologis serta mempertahankan nilainilai budaya yang ada di masyarakat setempat.

\section{DAFTAR PUSTAKA}

Achmad, A. (2017). Membangun Ekowisata Alam Liar. Makassar: Pusat Kajian Media dan Sumber Belajar LKPP Universitas Hasanuddin.

Arifin. (2011). Evaluasi Pembelajaran. Bandung: PT. Remaja Rosdakarya. 
Dinas Pariwisata Provinsi Jawa Tengah. (2002). Rencana Induk Pengembangan Pariwisata Jawa Tengah. Semarang: Dinas Pariwisata Provinsi Jawa Tengah.

Departemen Kebudayaan dan Pariwisata Indonesia. (2009). Prinsip dan Kriteria Ekowisata Berbasis Masyarakat. Jakarta: Departemen Kebudayaan dan Pariwisata Indonesia RI.

Gunawan. (2008). Agenda 21 Sektoral : Agenda Pariwisata untuk Pengembangan KualaitasHidup Secara Berkelanjutan. Jakarta: UNDP - Kantor Kementrian Lingkungan Hidup.

Hakim, L. (2004). Dasar-Dasar Ekowisata. Malang: Banyumedia Publishing

Honey, M. (1999). Ecoturism and Sustainable Development : How Owns Paradise. Washington DC: Island Press.

Josephine. (2010). Kajian Pengembangan Ekowisata di Kawasan Taman Wisata Alam Sibolangit. Medan: Universitas Sumatera Utara..

Kurniawan, J. dan Burhanuddin. (2004). Pengembangan Ekowisata di Kawasan Ekosistem Leuser. Medan: Program Pengembangan Leuser.
Kementrian Lingkungan Hidup dan Kehutanan. (2016, 30 Agustus). Setiap Tahun Hutan Indonesia Hilang. Kompas.com, Diakses pada 24 Oktober 2016 dari https://regional.kompas.com/2016/ 08/30/15362721/setiap.tahun.hutan.indonesia.hilang.684000. hektar.

Moleong, L. (1997). Metodologi Penelitian Kualitatif. Bandung: PT Remaja Rosdakarya.

Nursalam, dan Pariani. (2001). Pendekatan Praktis Metodologi Riset Keperawatan. Jakarta: Salemba Medika.

Supriatna, J. (2008). Melestarikan Alam Indonesia. Jakarta: Yayasan Obor Indonesia.

Soekadijo. (2000). Anatomi Pariwista. Jakarta: Gramedia.

Yoeti, O. A. (2000). Ekowisata Pariwisata Berwawasan Lingkungan. Jakarta: PT. Pertja.

Yoeti, O. A. (2008). Perencanaan dan Pengembangan Pariwisata. Jakarta: PT. Pradnya Pramita. 